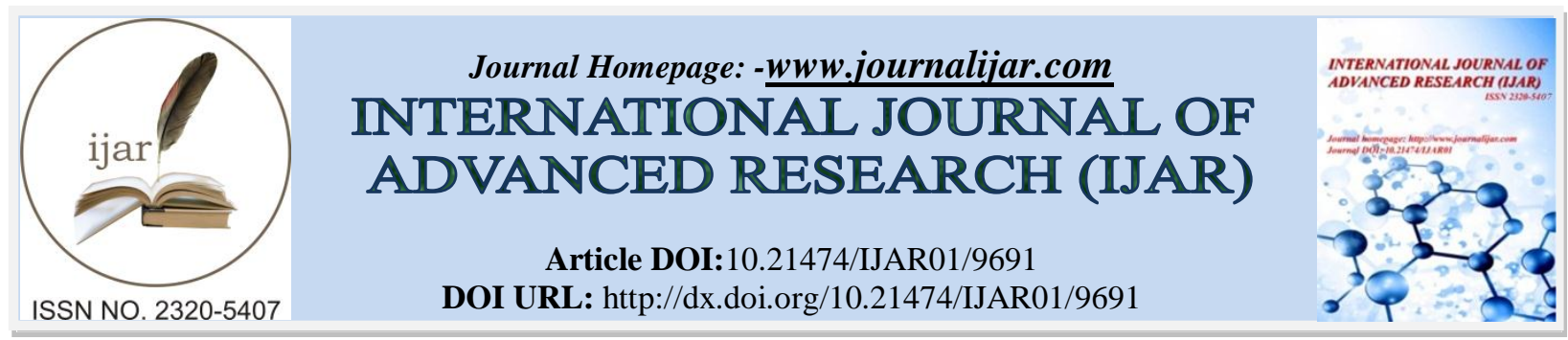

RESEARCH ARTICLE

\title{
ASSESSMENT OF COMMUNITY PARTICIPATION IN IMPLEMENTATION OF RURAL WATER SUPPLY SCHEMES: EMPIRICAL EVIDENCE FROM KILTEAWLAELO, ETHIOPIA.
}

\author{
Dr. Muthyalu Meniga ${ }^{1}$, Mr. Berhane Ghebremichaeal ${ }^{2}$ and Mr. Weldengus Desta Teferi ${ }^{3}$.
}

1. Associate Professor, Dept. of Cooperative Studies, College of Business and Economics, Mekelle University, Mekelle, Ethiopia.

2. Assistant Professor, Dept. of Cooperative Studies, College of Business and Economics, Mekelle University, Mekelle, Ethiopia.

3. Weldengus Desta Teferi, Legal Expert of vital events, Justice Office, Kilteawlaelo, Ethiopia.

\section{Manuscript Info}

Manuscript History

Received: 08 July 2019

Final Accepted: 10 August 2019

Published: September 2019

Key words:-

Community participation, rural water supply, water user committee, water sources.

\section{Abstract}

In the world, almost one in every ten people is without access to an improved potable and safe drinking water source. In Africa especially in sub-Saharan Africa are the most affected regions than other regions of the world. According to many research reports and documents the rural populations have less accessibility of safe and potable drinking water. Due to lack of safe and clean water and poor hygiene conditions many poor children are dying every day. The community participation is paramount important for sustainable rural water supply schemes. The government and other non-government organizations have been implementing different water supply schemes but they are unable to achieve their desirable goals due to different reasons. The main objective of this study was to assess the community participation in implementation of rural water supply schemes. This study used descriptive survey design. The multistage simple random sampling was used to obtain 255 household heads and 10 water users committee representing 10 water sources. The findings show that community participation was less very in the planning process which is very important, monitoring of the water supply schemes construction, contributing operation and maintenance charges. It is also found that water user committees' also low participation in the management of water supply schemes. It is concluded that due to poor socioeconomic conditions of the households they are not able to contribute to meet operation and maintenance charges. The selection of complicated technology has negative impacts on community participation in implementation of rural water supply schemes. To be successful of the any projects and schemes, participatory identifying and planning process are very crucial. Therefore, the study recommends that the concern agencies and officials should emphasis on community mobilization, and create awareness among the community.

Copy Right, IJAR, 2019,. All rights reserved. 


\section{Introduction:-}

The main challenges to provide safe and potable water are the population growth and climate change together present a significant challenge for urban and rural water providing agencies in developing countries in general, and of SSA in particular. (Brikké andVairavamoorthy, 2016). According to new report of WHO and UNICEF (2017) some 3 in 10 people worldwide or 2.1 billion, lack access to safe, readily available water at home, and 6 in 10 , or 4.5 billion, lack safely managed sanitation. The important community model among the various suggested models is the community demand driven approach as opposed to the traditional supply driven approach (Naiga et al, 2012; Nicole, 2000; World Bank, 1998). The main health problems, especially in developing countries like Ethiopia, are results of poor access to potable water, poor hygiene, and sanitation practices. In these cases, supplying safe drinking water is of critical importance. Safe water and sanitation also shape health through potable water supply, safe food preparation, hygiene, better nutrition, and entertainment (Misgina, 2006). Billions of people have gained access to basic drinking water and sanitation services since 2000, but these services do not necessarily provide safe water and sanitation. Many homes, healthcare facilities and schools still lack soap and water for hand washing. This puts the health of all people especially young children at risk for diseases, such as diarrhea and other diseases. As a result, every year, 361000 children under 5 years of age die due to diarrhoea. Poor sanitation and contaminated water are also linked to transmission of diseases such as cholera, dysentery, hepatitis A, and typhoid (Joint Monitoring Programme report 2017).

The concept is anchored in the idea of Community Participation (CP) which advocates greater beneficiary involvement in water service production and management (Whittington et al, 2009). It includes beneficiaries taking the initiative to demand improved water services while at the same time taking a leading role in project design, implementation, development and sustainability. The demand-responsive approach requires beneficiaries to own the system by constantly making meaningful contributions either in the form of cash or labor to community-based water projects (Sara \& Katz, 1998). Government and non-government organizations have been spending billions of money in the provision of rural water supply systems in developing countries over the past three decades. Although progress is being made and rates of coverage are increasing, users often find that, once installed, low community participation, water supply systems are poorly maintained and eventually break down, leaving them with an unreliable and disrupted water supply schemes' (Lockwood and Smits, 2011). Worldwide and in Ethiopia significant number of children are dying each day because of lack of safe drinking water and appropriate sanitation and hygiene. Until recent years, the Ethiopian water sector development activities lack comprehensive water resources management policy. As a result, the water supply and other water sector development activities were performing at low level compared to other countries and sectors. One of the major reasons for this low level of achievement is lack of integration and coordination of these activities. Because of this existing problem the government prepared and endorsed the Ethiopian Water Resources Management Policy (MoWR, 1999). Within this policy there are integrated water supply and sanitation, and irrigation policies with the general objective of enhancing the well-being and productivity of Ethiopian people. There are studies at national and regional which are conducted on sustainability of water supply schemes. Misgina (2006) conducted a study and focused on sustainability aspects of Rural Water Supply: he discussed factors that influence sustainability of rural water schemes. The most of the previous studies sustainability issues only.

Community management of water services has been developed as a solution in the most disadvantaged suburban areas. The populations in these areas form user associations, water committees, community assemblies or water cooperatives. The recipient population makes the investments, thereby compensating for the authorities' inability to provide the service (European Union 2010). The study conducted by Francesca Fulgoni (2008) shows the relationship between tariff setting and scheme sustainability focusing on financial factors only. In other words, the study examined the importance of increasing tariff or increasing water consumption to ensure the sustainability by applying the cost recovery principle. There are no much studies conducted on community participation in rural water supply schemes in the country as well as in the Tigrai Region. An assessment of community participation in rural water supply schemes at pre, during and post-construction phases are critical for Ethiopia and particularly for the kilteawlaeloWoreda. It will be useful to have sufficient scientific information before launching large investments in rural water supply schemes. Thus, there is a need to conduct a research on community participation in the implementation of rural water supply schemes. The researchers believed that the present study will provide suggestions and scientific information for improving the community participation so as to rural water supply schemes will be implemented very effectively and efficiently. 


\section{Objectives of the research study}

1. To assess the community participation in planning, designing, implementation and monitoring of the rural water supply schemes

2. To examine the beneficiaries satisfaction towards rural water supply schemes and the water management committees of the water supply schemes

\section{Methodology of the study:-}

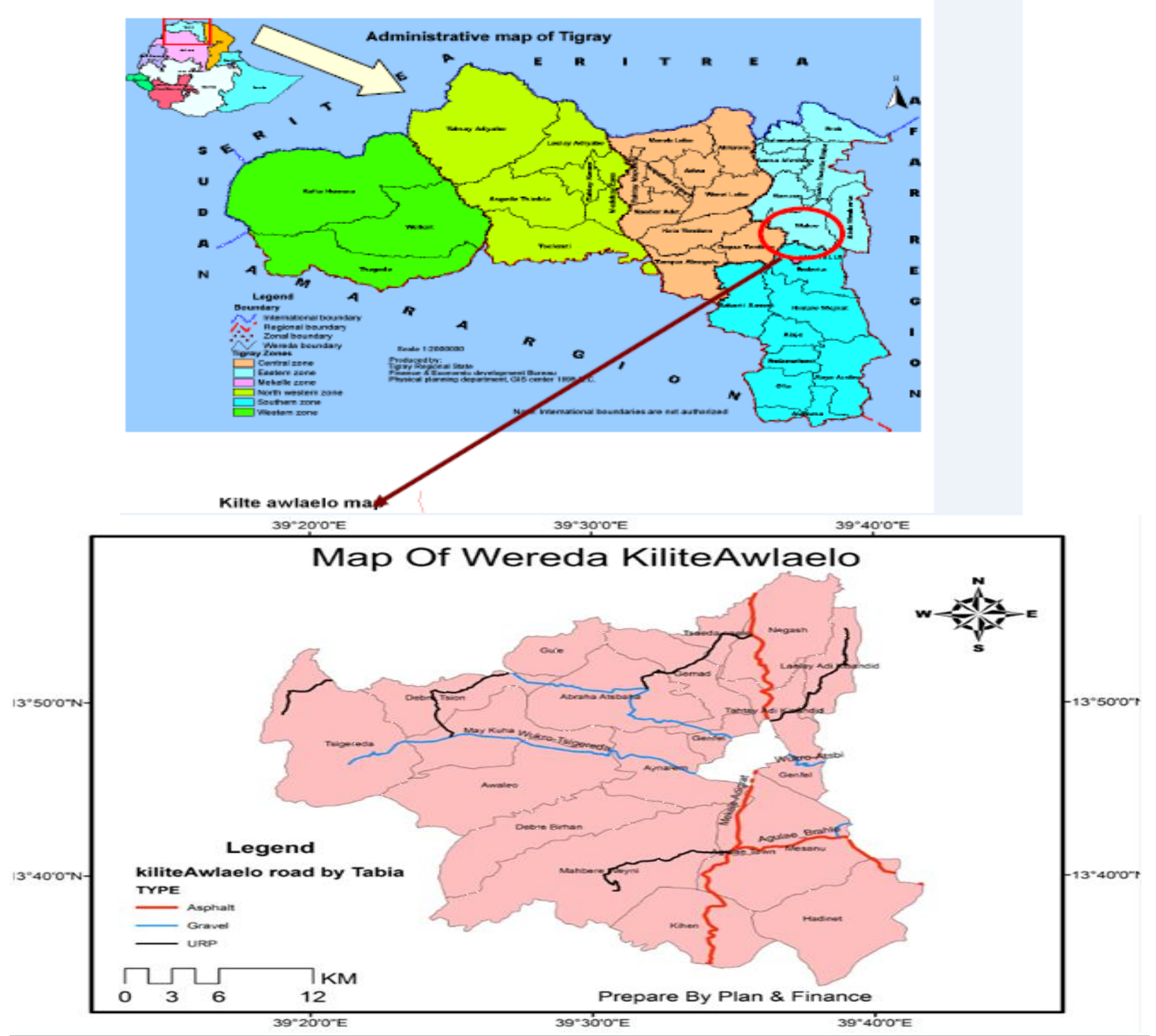

Source; plan and finance of kilteawlaeloworeda

The study was used cross-sectional research design. In this method, data collect on different issues at one point in time.Both quantitative and qualitative data were collected to meet research objectives from the primary and secondary sources. The quantitative primary data has been collected from the sample respondents by using interview methodwith the help of pre-tested interview schedule. The qualitative primary data were collected by observation, Focus group discussion, and key informants interviews.

A multistagerandomsampling technique has been used to select study area and samplerespondents. In the first stage, Kilteawalaeloworedaselectedpurposivelybecause of there are many water supplyschemes, no researchstudiesso far, researcherfamiliarwithworeda etc. In the second stage, four kebeles out of 19 kebeleswereselectedby using simple 
randomsampling. In the third stage, 10 rural waterschemeswereselected by usingstratifiedrandomsampling. The water supplyschemeswerecategorizedintothree stratums likedeepwells, shallowwells, and hand dugwells. Fromshallowwells 6 water schemes, from hand dugwell 3 water schemes, and deepwell 1 water scheme have been selected by simple randomsampling technique. In the final stage from the 707 households 255 samplerespondentsfrom 10 water schemes have been selected by simple randomsampling techniques.

Sample size determined by Yamane's (1967) formula:

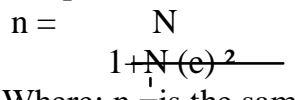

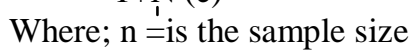

$\mathrm{N}=$ is the population size,

$\mathrm{e}=$ is the level of precision.

So out of 707 house hold beneficiaries of the ten water schemes are

$$
\begin{aligned}
\mathrm{n} & =\quad \begin{aligned}
707 \\
1+707 \cdot(0.05)^{2}
\end{aligned} \\
& =255 \text { respondents are the sample size }
\end{aligned}
$$

After collection of the primary and secondary data, the researchers have done editing, coding and tabulation of the data. Based on the nature of the data, different data analysis methods qualitative and Quantitative methodswere used for data analysis. Descriptive statistical method like central tendency, percentages, and ratios used to draw meaningful inference in line with the objectives of the study. On the other hand, qualitative data gathered from key informant interview, FGD, direct observation and document review first organize and categorize thematically and used in interpretation part of the study results.

\section{Results and discussions:-}

Table 1:-Respondents distributed by age and marital status

\begin{tabular}{|l|r|r|l|r|r|}
\hline \multicolumn{2}{|c|}{ Age } & \multicolumn{2}{c|}{ Marital Status } \\
\hline Years & frequency & Percent & Status & frequency & percent \\
\hline $18-25$ & 6 & 2.4 & Married & 179 & 70.2 \\
\hline $26-30$ & 2 & .8 & Single & 8 & 3.1 \\
\hline $31-35$ & 43 & 16.9 & Divorced & 26 & 16.5 \\
\hline $36-40$ & 75 & 29.4 & Widowed & 255 & 100.2 \\
\hline $41-50$ & 97 & 38.0 & Total & & \\
\hline$>50$ & 32 & 12.5 & & & \\
\hline Total & 255 & 100.0 & & & \\
\hline
\end{tabular}

Source: Primary data, 2018

Table 1 shows that the ages of the sample respondents, 6(2.4\%) were ages between 18-25, 2(0.8\%) were ages between 26-30 years, 43(16.9\%) were ages between 31-35 years, $75(29.4 \%)$ were ages between $36-40$ years, 97(38\%) were ages between 41-50 years, and 32(12.5\%) were ages above 50 years of ages. The active population that fall between 18 and 50 years of ages were very active and had good understanding on new technologies but they were low understanding of water as a precious. On the other hand the older who were greater than 50 years of ages had good understanding of water is a precious since they have been suffering for last few years, but they do not know the new technologies as possible as needed.

Out of the respondents of the survey, $8(3.1 \%)$ were single, $179(70.2 \%)$ were married, $42(16.5 \%)$ were divorced, and only 26(10.2\%) were Widowed. This implies that majority of the respondents are married. Marriage is a habit in the rural community to work any activity together or in unity which made them strong mutual support. Mostly agricultural and livestock rearing are activities which need cooperation of wife and husband. Married respondents had good perception upon community participation in water supply schemes. This is because their water consumption and need is very high due to family size and discipline life. But the unmarried respondents do not care about the water supply schemes since their need is very low as well as consumption too. 
Figure: 1 Respondents distributed by purposes of water using

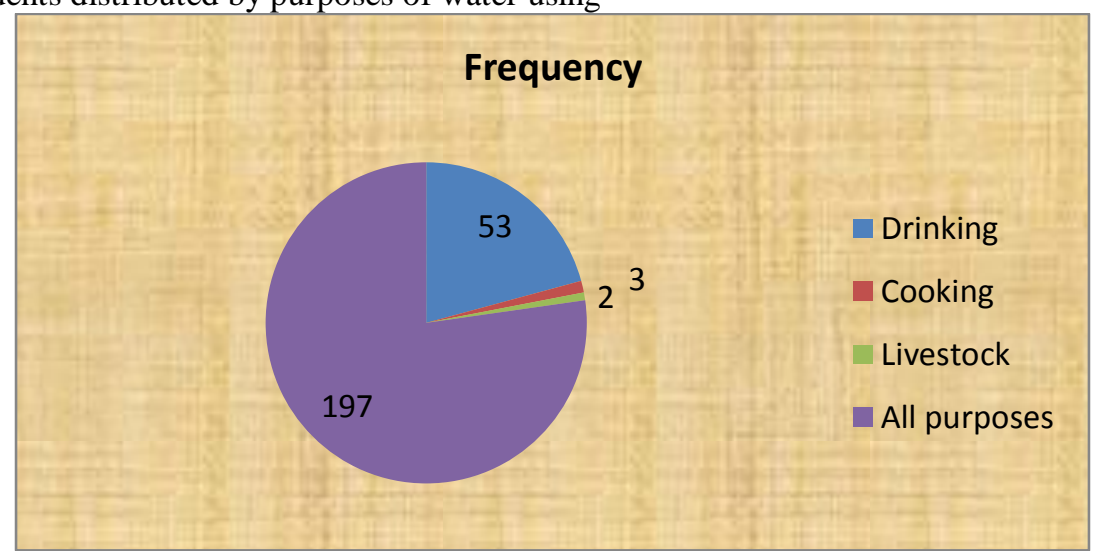

Source: Primary data, 2018

The survey result shows that, 53(20.8\%) of the respondents have reported that they use water for drinking purpose, 3 $(1.2 \%)$ of them said that they are using for both drinking and cooking, $2(0.8 \%)$ of the respondents have stated that for livestock and $197(77.2 \%)$ of the respondents stated that they are using water for all above purposes. It is concluded that water is prime important for above four purposes.According to focus group discussions made with water committee's at Mesanukebelle, they have reported that, they use water in effective and efficient manner during the shortage of the water. This findings show that majority $77.2 \%$ respondents were using water for all purposes. Furthermore, they stated that there is no alternative source for drinking water purpose. They can water Form Rivers and other unprotected sources for washing, cooking, livestock, etc.

Table 2:-Water source location, Water fetching responsibility, and mode of water carrying

\begin{tabular}{|c|c|c|c|}
\hline Issues & Response & Frequency & Percent \\
\hline \multirow{6}{*}{$\begin{array}{l}\text { The location of the water } \\
\text { source to your household }\end{array}$} & Convenient & 82 & 32.2 \\
\hline & Inconvenient & 106 & 41.6 \\
\hline & Very convenient & 36 & 14.1 \\
\hline & Very inconvenient & 7 & 2.7 \\
\hline & Fair & 24 & 9.4 \\
\hline & Total & 255 & 100.0 \\
\hline \multirow{5}{*}{$\begin{array}{l}\text { Who is the responsible } \\
\text { for fetching } \\
\text { water }\end{array}$} & Men & 22 & 8.6 \\
\hline & Women & 18 & 7.1 \\
\hline & Children & 54 & 21.2 \\
\hline & Women \& children & 161 & 63.1 \\
\hline & Total & 255 & 100.0 \\
\hline \multirow[t]{5}{*}{ Mode of water carrying } & Human being & 68 & 26.7 \\
\hline & Donkey & 172 & 67.5 \\
\hline & Donkey pulled cart & 3 & 1.2 \\
\hline & Other & 12 & 4.7 \\
\hline & Total & 255 & 100.0 \\
\hline
\end{tabular}

Source: Primary data, 2018

Table 2 revealed that 41.6 Percent of the sample respondents reported that the location of the water source is inconvenient to their houses, where as 32.2 percent of the sample respondents said that location of the water source is convenient to their houses. $14.1 \%$ of the respondents opined that it is very convenient to their houses. The survey results show that more than $50 \%$ of the respondents are satisfy with the location of the water source. Further, the study results revealed that most of the time water fetching done by women and children. Due this burden female students are not able to attend their school and it has been affected on their academic performance. Table 2 depicted that $(63.1 \%)$ of the sample respondents stated that women and children bring water to their houses. $22(8.6 \%)$ responded that only men brings water to their home, 18(7.1\%) responded that only women bring water to their home, From this one can understand that women and children are the responsibility for bringing the water. 
The survey result shows that $68(26.7 \%)$ of the respondents stated that they bring water by human beings (by head or shoulder carrying), $172(67.5 \%)$ responded that they bring water by donkey, $3(1.2 \%)$ responded that they bring water by donkey pulled cart and $12(4.7 \%)$ responded that they bring by both human being and donkey. It is concluded that most of the respondents are using donkeys for water carrying.

Figure2 :-Respondents' opinions regarding to quality of the water supplyschemes

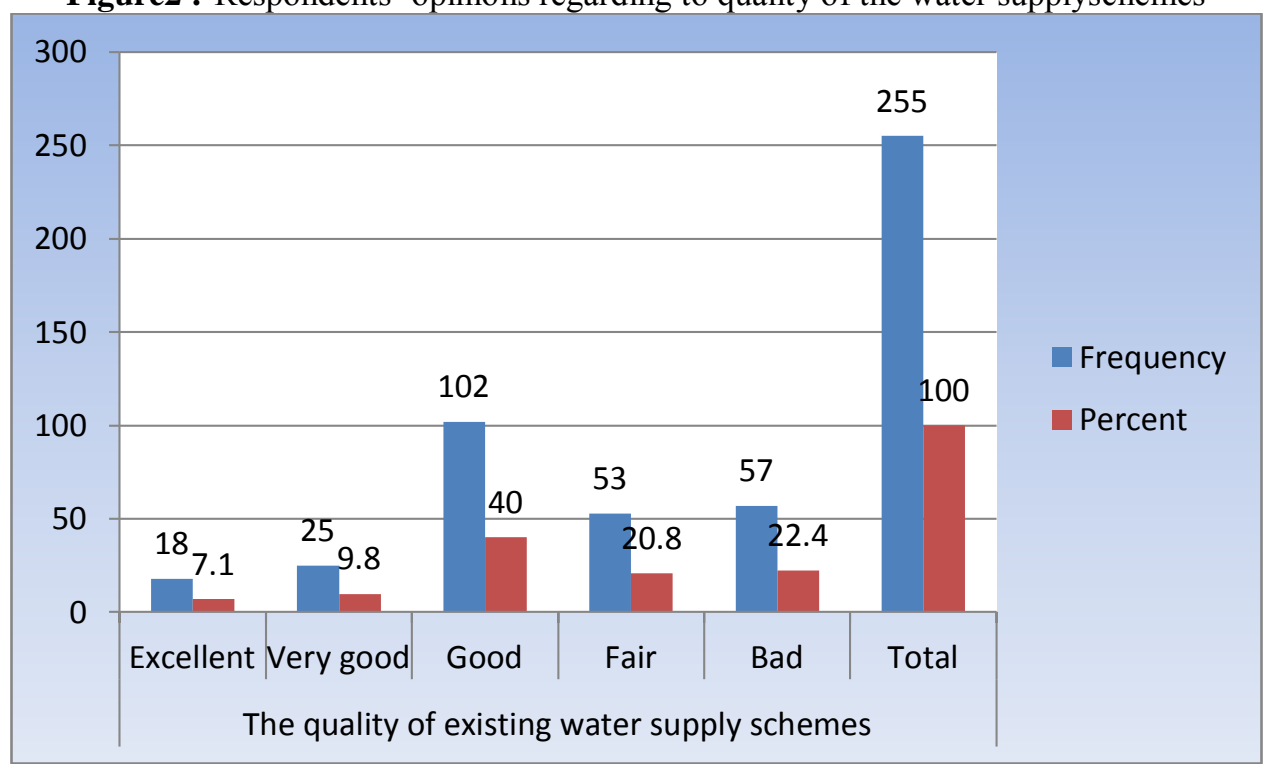

Source: Primary data, 2018

Construction quality plays a great role in water supply schemes. The survey result revealed that, 18(7.1\%) of the sample respondents reported that the construction quality is "Excellent", 25(9.8\%) of the respondents said that the construction quality is very good, $102(40 \%)$ of the respondents said that the construction quality is good, 53(20.8\%) of the respondents said the construction quality is fair and $57(22.4 \%)$ of the respondents said the construction quality is bad. The researcher observed in his personal observation and noticed that some of the water supply schemes construction was poor. For example, the drainage ditches were not constructed according to the stipulated standard which should be in relation to the characteristics of the area.

Table 3:-Community participation process in water supply schemes

\begin{tabular}{|c|c|c|c|}
\hline Issues & Response & Frequency & Percent \\
\hline \multirow{3}{*}{$\begin{array}{l}\text { Community participate in } \\
\text { decision-making in project } \\
\text { development, planning and } \\
\text { implementation }\end{array}$} & Yes & 164 & 64.3 \\
\hline & No & 91 & 35.7 \\
\hline & Total & 255 & 100.0 \\
\hline \multirow{6}{*}{$\begin{array}{l}\text { The time or phase of } \\
\text { participation }\end{array}$} & During planning & 8 & 3.1 \\
\hline & During construction & 82 & 32.2 \\
\hline & Post construction & 21 & 8.2 \\
\hline & $\begin{array}{l}\text { During and post } \\
\text { construction }\end{array}$ & 43 & 16.9 \\
\hline & In all phases & 10 & 3.9 \\
\hline & Total & 164 & 100.0 \\
\hline \multirow[t]{5}{*}{ Type/form of participation } & Information provision & 26 & 10.2 \\
\hline & Money contribution & 33 & 12.9 \\
\hline & Labor contribution & 51 & 20.0 \\
\hline & $\begin{array}{l}\text { Supply of locally } \\
\text { available materials (rock, } \\
\text { sand,laboretc) }\end{array}$ & 54 & 21.2 \\
\hline & Total & 164 & 100.0 \\
\hline
\end{tabular}




\begin{tabular}{|l|l|r|r|}
\hline \multirow{3}{*}{$\begin{array}{l}\text { Reasons for not } \\
\text { participating }\end{array}$} & Not asked & 31 & 12.2 \\
\cline { 2 - 4 } & $\begin{array}{l}\text { Everything is done by the } \\
\text { implementing agency }\end{array}$ & 27 & 10.6 \\
\cline { 2 - 4 } & Lack of awareness & 33 & 12.9 \\
\cline { 2 - 4 } & Total & 91 & 100.0 \\
\hline \multirow{2}{*}{$\begin{array}{l}\text { The sites for construction } \\
\text { were } \\
\text { selected by: }\end{array}$} & Community & 62 & 24.3 \\
\cline { 2 - 4 } & $\begin{array}{l}\text { Implementing agency } \\
\text { alone }\end{array}$ & 48 & 18.8 \\
\cline { 2 - 4 } & water specialist (experts) & 132 & 51.8 \\
\cline { 2 - 4 } & Others & 12 & 4.7 \\
\cline { 2 - 4 } & Total & 255 & 100.0 \\
\hline
\end{tabular}

Source: Primary data, 2018

Table 3 presents the community participation and type of participation in the water supply schemes. The survey results revealed that $64.3 \%$ of the sample respondents have been participating at different levels of the water supply schemes, while the remaining $91(35.7 \%)$ have not participated in the water supply projects or schemes. Simple participation has no meaning unless they active participate in all phasesof the projects. There is need to participation from starting to termination, and continuing for future which could help sustainability of the water supply schemes.This finding confirms with Arlosoroff et al. (1987) strongly argued that the highest potential for sustainability is achieved when the community is involved in all phases of the project starting from the planning stage.

The study results portray only $8(3.1 \%)$ respondents have participated during the planning stage which is very less participation in the planning process of water supply schemes. Further, the study results show that of total sample respondents who have participated $82(32.2 \%)$ sample respondents have participated during the implementation/construction of the water supply schemes. About $8 \%$ of the respondent stated that they participated in post-construction phase, $43(16.1 \%)$ respondents were participated both during and post-construction phase, and only $10(3.9 \%)$ were participated in all phases i.e planning, implementation and post implementation. With regard to this (IDRC,1981) highly recommended and emphasized the need of active community participation in the planning, implementation/construction, operation and maintenance $(\mathrm{O} \& \mathrm{M})$ and evaluation phases of rural water supply projects. It is concluded that very few respondents were participated in planning phase which is highly important phase in water supply schemes, without local community participation and their support any projects or schemes will not be sustainable

Regarding to type/form of participation 51 (20\%) respondents stated that they participated in providing labour contribution to construction of water supply schemes. The study results present that out of 164 participated respondents 33(12.9\%) were participated by money contribution, while 6(10.2\%) respondents said that they participated in information giving and $54(21.2 \%)$ by supply of locally available materials (stone, sand, etc).It is concluded that most of the respondents participated in labour contribution and supply of locally available material for the construction of the water supply schemes.

Table 3 presented reasons for not participation in the water supply schemes. Table 3 revealed that out of 91 non participated respondents $31(12.2 \%)$ of them stated that there is no information and community were not asked by concern officials and agencies to participate in the water supply schemes. The study results portray that 33(12.9\%) of the respondents were not participated due to lack of awareness. Remaining 27(10.6\%) respondents opined that government and implementing agency done by everything without informing to the concern community members. It is concluded that community were not well informed and mobilized properly to engage them in the different stages of the projects. Absence of community participation may lead to failure of the project and unachievable of the desired projects goals. Is is suggested that concern officials and implementing agencies have to emphasize and educate the community to active participation at different phases of the water supply schemes.

Water committee members stated that during the focus group discussions women participation is paramount important in water supply schemes sustainability. Women know the pain of the water scarcity and its consequences. Therefore, women participation can minimize their challenges as well as they can maintain properly water schemes. Further during the discussion with women at Mesanukebele, they also strongly recommended the importance of 
women participation on rural water supply programs. Furthermore they said that women are the vulnerable groups by fetching water from water point, their participation can give very good information for stakeholders rather than men.

The survey result indicated that $62(24.3 \%)$ of respondents revealed that decision for site selection were made by community, $48(18.8 \%)$ were by implementing agency alone, $132(51.8 \%)$ were by water specialist (experts) ( e.g. from, woreda, etc), and $12(4.7 \%)$ of the respondents answered that they did not know who decide the site selection. This findings shows that most of the decision making process were done by the implementing agencies alone, and water specialist (experts) from and woreda water office. But, the decision making were not including community who are the owner of the water supply schemes. Absence of communities in site selection would have a negative impact on sustainability of the water supply schemes as decisions were mainly made by implementing agencies alone.

Table 4:-Importance of community water management committee and their selection process

\begin{tabular}{|l|l|r|r|}
\hline Item & Response & frequency & Percent \\
\hline Is community water management committee is & Yes & 231 & 90.6 \\
\cline { 2 - 4 } necessary? & No & 24 & 9.4 \\
\cline { 2 - 4 } & Total & 255 & 100.0 \\
\hline \multirow{5}{*}{ Water committee members were selected by: } & Community & 216 & 84.7 \\
\cline { 2 - 4 } & Woreda water office & - & - \\
\cline { 2 - 4 } & Kebele administration & - & - \\
\cline { 2 - 4 } & NGOs & - & - \\
\cline { 2 - 4 } & Community and & - & - \\
& Woreda water office & 39 & 15.3 \\
\cline { 2 - 4 } & All in collaboration & 255 & 100.0 \\
\cline { 2 - 4 } & Total & & - \\
\end{tabular}

Source: Primary data, 2018

Figure 3:-Time of water management committee established

\section{Time of committee established}

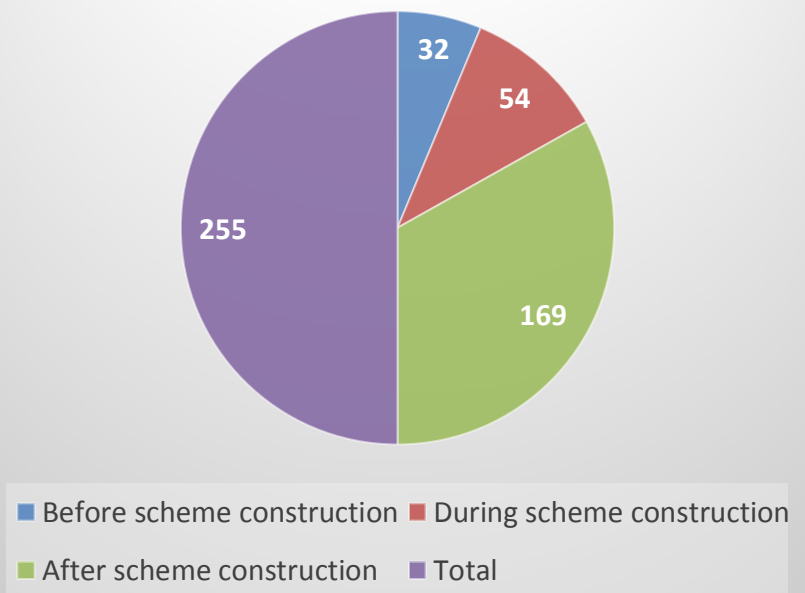

Source: Primary data, 2018

The study results indicated that $231(90.6 \%)$ of the respondents stated that the community water management committee is very essential to smooth implementation and management of the water supply schemes. Whereas $24(9.4 \%)$ of the respondents said that the committee is not the right way to implement and management water supply schemes. It is concluded that majority of the respondents agreed to establish the community water management committee to effective implementation of the schemes. 
The sample respondents were asked about the selection of the water committee members. Out of 255 sample respondents $216(84.7 \%)$ of the sample respondent stated that the water committee members selected by the community. Whereas $39(15.3 \%)$ reported that committee members selected by in collaboration with community and woreda water office. One can understand that majority respondents were participated in selection of the committee members which is good indication of the community participation in selecting committee members.

The time of selection or establishment of water committees is very important to smooth and effective execution of the schemes. The respondents were asked the time of selection of the water committee members. The study results indicate that $169(66.3 \%)$ of them reported that the committee members were selected after scheme construction. $54(21.2 \%)$ of them stated that the committee members were selected during the scheme construction, whereas $32(12.5 \%)$ of sample respondents stated that the water committees was established before construction of the scheme. It is concluded that the water committee was established after construction of the schemes which will affect the quality and governance of the water supply schemes. As indicated above majority of the sample respondents stated that water management committee is very important but the committee is not established on proper time. It is suggested that the community water management committee should be formed before beginning of the schemes so as to committee members get awareness and they participate actively in all aspects of the water supply schemes.

Table 5:-Level of community satisfaction with the water schemes service

\begin{tabular}{|c|c|c|c|}
\hline Issues & Response & Frequency & Percent \\
\hline \multirow{4}{*}{$\begin{array}{l}\text { Are you satisfied with the } \\
\text { water quality and pressure } \\
\text { of the source? }\end{array}$} & Very satisfied & 31 & 12.2 \\
\hline & Satisfied & 115 & 45.1 \\
\hline & No satisfied & 109 & 42.7 \\
\hline & Total & 255 & 100.0 \\
\hline \multirow{4}{*}{$\begin{array}{l}\text { Are you satisfied with the } \\
\text { number of hours available? }\end{array}$} & Very satisfied & 66 & 25.9 \\
\hline & Satisfied & 128 & 50.2 \\
\hline & No satisfied & 61 & 23.9 \\
\hline & Total & 255 & 100.0 \\
\hline
\end{tabular}

Source: survey result 2018

Community satisfaction is the indication of the success of the projects. The study assesses the community satisfaction with regard to water supply schemes. The study results indicated that $109(42.7 \%)$ of respondents were not satisfied with water quality and pressure whereas $31(12.2 \%)$ and $115(45.1 \%)$ were very satisfied and satisfied respectively. It is concluded that more than one third of the sample respondents were not satisfied with water quality and pressure of the water source so implementing agencies and water committees should focus to provide quality and adequate water to the community. Furthermore, the study focused on the number of hours available of the water. The study results portray $66(25.9 \%)$ of respondents stated that they are very satisfied with the number of hours available of the water.128 (50.2\%) of respondents were satisfied with the number of hours available, 61(23.9\%) of respondents were not satisfied with the number of hours available. it shows that almost one fourth of the respondents are not satisfied with availability of the water.

\section{Conclusions:-}

Sustainable water supply schemes play a greater role in providing potable water and good hygienic conditions which leads to reduce water related problems, health issues so as to poor people can lead good life and wellbeing in the developing countries. In the present development era demand driven approach can enhance people's participation which will contribute to sustainable rural water supply schemes. The study results indicated that the primary stakeholders are not participated in the important stages of the water supply schemes like identifying, planning and execution of the schemes which leads to poor quality, poor sense of ownership, and ineffective monitoring mechanism. To be successful and sustainable of the any water supply schemes the primary stakeholders should take part in each and every phase of the projects. Women and children are the vulnerable and major victims of the waterrelated problems and poverty; therefore, women and youth participation in rural water supply schemes is very essential. In the demand driven approach local committees and associations can motivate and mobilize the community to involve in the development process so there is a need to form and establish different committees at appropriate time in every rural water supply schemes. Development through education is the principle of the development process so the primary beneficiaries or stakeholders should educate before starting of the projects so as to they can cooperate and contribute their inputs to effective implementation of the rural water supply 
projects/schemes. To avoid challenges in rural water supply schemes local communities, associations, youth, and gender balance are paramount important in planning and decision making of the schemes.

\section{References:-}

1. Brikke F, Vairavamoorthy K, 2016. Managing Change to Implement Integrated Urban Water Management in African Cities. Aquatic Procedia 6: 3-14.

2. European Union, (2010), Water Sector Development and Governance: Complementarities and synergies between Sector wide approach and Integrated Water resource Management, Luxembourg, Publication Office of the European Union.

3. Joint Monitoring Programme report (2017), world health organization report on Progress on drinking water, sanitation and hygiene

4. Lockwood, H. (2004), Scaling Up Community Management of Rural Water Supply, IRC,Ministry of water resources (MoWR), (2005) Ethiopian water resources management policy, Berhanenaselam printing enterprises, Addis Ababa, Ethiopia.

5. MisginaGebrehiwot (2006) An assessment of challenges of sustainable rural water supply: the case of Ofloworeda in Tigrai Region.

6. Naiga, R., Penker, M., \&Hogl, K. (2012). From supply to demand driven water governance: challenging pathways to Safe Water Access in Rural Uganda.

7. Sara, J., \& Katz, T. (1998). Making rural water supply sustainable: Report on the impact of project rules. Washington DC. The World Bank.

8. Whittington et.al, (2009) experiences and challenges of community participation in urban renewable projects: A case of Johannesburg, South Africa.

9. World Bank (1998). Demand Responsive Approaches to community water supply; Moving from policy to practice, East and Southern Africa World Bank. 